Egyptian Journal of Rabbit Science, 26(1): 1 - 19(2016)

\title{
EFFECT OF GUAR KORMA MEAL IN NEW ZEALAND WHITE DOE RABBITS DIETS ON PRODUCTIVE AND PHYSIOLOGICAL PERFORMANCE
}

\author{
Fadila M. Easa; Hemat A. Abdel Magied and Amal M. Hekial \\ Animal Production Research Institute, Agriculture research Center, Dokki , \\ Giza, Egypt.
}

This study was conducted to investigate the effect of inclusion of guar korma (Gyamopsis tetragonloba L.) meal (GKM) in rabbit diet on performance of New Zealand White (NZW) does during gestation and lactation on growth performance of weanlings. Forty multi-parious does 8-12 month old were allocated to five GKM dietary treatments: 0.0 (control), 2.5, 5.0, 7.5 and 10.0\%. Does were naturally inseminated and housed separately in individual wired-cages. All animals were kept under the same management and hygienic conditions. Parameters live body weight and feed intake for does after gestation and lactation period were recorded. Also milk yield, litter size and litter weight were recorded weekly. Feed cost and some blood parameters were studied. Results indicated that feeding 5.0\% GKM significantly increased feed intake during gestation and lactation, while feeding 7.5 and $10.0 \%$ GKM diets resulted in inferior feed intake. Does fed on $5.0 \%$ GKM recorded significantly the highest milk yield during four weeks of lactation compared with other groups. Litter size at birth and weaning were significantly higher in the control and 5.0\% GKM groups than 2.5, 7.5 and 10.0\% GKM group. Litter weights at birth and corresponding litter weight gains and through 4-week lactation period were increased with dietary GKM 5.0\% while it decreased in the rest of treatments. Also, GKM at 2.5 and $5.0 \%$ recorded the higher kid weight, kid weight gain and kid daily gain compared with the other groups. Total protein, albumin, globulin and glucose concentrations were increased with feeding on 5.0\% GKM diet compared with other treatments, while control showed the highest concentration of triglycerides, total cholesterol, high density lipoprotein (HDL), and low density lipoprotein (LDL) in plasma. Adding the GKM to doe rabbits diet did not alter transaminase (aspartate aminotransferase, AST and alanine aminotransferase, ALT) activity. The lowest feeding cost per 
weaned recorded with 5.0\% GKM group compared with other treatments.

Based on the overall obtained results it could be recommended to include guar korma meal in doe-rabbits diet up to $5.0 \%$ of the diet without negative effect on performance during gestation and lactation periods with saving cost of feeding with 5.0\% GKM.

Key word: Guar Korma Meal, Doe Rabbits, Gestation, Lactation, Blood Parameters.

Providing alternative feeding materials could participate to decrease the extraordinary increase in conventional feed-stuffs used in formulating rabbit diets.

Guar, Cyamopsis tetragonoloba L. (syn. C. psoraloides) or cluster bean is a drought-tolerant summer annual legume native to India and Pakistan (Rahman and Shafivr, 1967). Guar meal is a relatively inexpensive high protein meal produced as a by-product of guar gum manufacture. It is a mixture of germs and hulls at an approximate ratio of $25 \%$ germ to $75 \%$ hull (Lee et al., 2004). The high amino acid content of the guar meal protein makes it a useful protein supplement for mono-gastrics. Since the germ fraction of guar meal contains energy, protein, methionine and phosphorus in higher levels than that in soybean meal (SBM), addition of guar meal as a partial replacement $(<10 \%)$ of SBM in poultry diets may be a useful economic strategy for decreasing feed cost without any negative effects on production (Kamran, et al. 2002). The germ contains most of the protein in seed, the protein content of guar meal ranges between 33 to $45 \%$ depending on fraction types (Conner 2002). The chemical composition of GKM versus SBM observed (Walaa et al., 2014) in Table 1.

Some of the anti-nutritional agents (trypsin inhibitors, gum residue, saponins, haemagglutinins, hydrocyanic acid and polyphenols) present in guar meal limit its usage at high levels in poultry diets (Anderson and Warnick, 1964). Therefore, growth inhibition that follows the inclusion of guar meal in poultry diet may be attributed to the residual gum content of the meal (Lee et al., 2005). While, the large saponins content of guar seed (up to $13 \%$ DM) could have both antinutritionals effect and a positive antimicrobial activity (Hassan et al., 2010). Guar meal can also be used as a binding agent in feed formulation. It is characterized as free flowing, has light greenish color and coarse texture and more importantly, guar meal is free from salmonella, E. coli, and aflatoxin (Lee et al., 2009). 
Table 1: Chemical composition (\%) of guar korma meal (GKM) and soybean meal (SBM) according to (Walaa et al., 2014).

\begin{tabular}{|lcc|}
\hline Items & GKM & SBM \\
\hline Organic matter & 94.37 & 93.60 \\
Crud protein & 49.22 & 44.00 \\
Crude fiber & 8.53 & 3.90 \\
Ether extract & 5.10 & 1.90 \\
Ash & 5.63 & 6.40 \\
Nitrogen free extract & 31.52 & 43.80 \\
Digestible energy $(\mathbf{k c a l} / \mathbf{k g})$ & 3162.00 & 3202.00 \\
\hline
\end{tabular}

Excessive concentrations of guar meal in poultry diets caused diarrhea, depressed growth rate and increased mortality of broilers (Rahman and Leighton, 1968). Heat treatments and fermentation have been proposed to improve the nutritive value of guar and most of the toxic and anti-nutrient effects could be removed by processing methods such as soaking, germination, boiling, autoclaving and fermentation (Srivastava et al 2011).

Guar meal can be used as a feed ingredient at level $2.5 \%$ of Inshas chicks diets without any adverse effect on growth performance (Nasrala et al., 2015). Also, Salma et al., (2015) reported that guar meal could replace $25 \%$ of SBM (equal 6.75 and $6.25 \%$ form diets for starter and grower respectively) in broilers diets without adverse effects on growth performance, blood lipids or economical efficiency, however inclusion high levels of guar meal in broiler diets caused deleterious effect growth performance. In growing-finishing pig, the inclusion of guar meal up to $6 \%$ had no negative effects on growth performance. Guar meal inclusion at $12 \%$ reduced growth without affecting pork meat quality (Heo et al., 2009). Unfortunately no available studies on evaluation of rabbit response to incorporation of guar korma meal in the diet.

Therefore, the objectives of the present study were to investigate the effect guar korma meal on performance of doe New Zealand White rabbits during gestation and lactation periods and some of physiological parameters.

\section{MATERIALS AND METHODS}

This study was carried out at Sakha Research Station, Animal Production Research Institute (APRI), Egypt.

\section{Experimental animals, design and management:}

Forty multi-parious New Zealand White does 8-12 month old were equally allocated to five GKM dietary treatments: 0.0 (as control treatments), 
2.5, 5.0, 7.5, 10.0\% (8 does/treatment), does were naturally inseminated. Detection of conception was carried out by palpation at 10 days after mating and the non pregnant were remated immediately. Does were housed in individual wired-cages. All animals were kept under the same management and hygienic conditions and provided with fresh water and pelleted diets, ad-libtum over the experimental period.

\section{Experimental diets and measurements:}

Diets were formulated to meet the NRC'1977 requirements during gestation and lactation periods. Ingredients and calculated chemical analyses of experimental diets are presented in Table 2. Recording of does weight, Feed intake, litter size and weight at birth and weekly up to weaning were done. The change in live body weight during gestation period was calculated as the difference between the live body weight at mating and body weight after post partum, while the change in live body weight during suckling was calculated as the difference between the live body weight at the end of suckling period (at weaning) and the body weight post partum, in which the kids became four weeks of age. Milk yield was recorded twice a week for each doe as the increase in kids weight, resulted from weighting the kids before and after suckling, kids were subjected to 24 hours deprivation before measuring milk yield from suckling their mothers. Also, feeding cost during experimental period was calculated. Individual blood samples were collected from three does each treatment from the marginal ear vein in $5 \mathrm{ml}$. heparinized test tubes and centrifuged at 3000 r.p.m for 20 minutes then plasma were stored at $-20^{\circ} \mathrm{C}$ until the time of chemical analysis. Chemical analysis of the blood plasma included plasma total protein, albumin, globulin (determined by subtraction the value of albumin from total protein of the same plasma sample), transaminase (aspartate aminotransferase, AST and alanine aminotransferase, ALT), glucose, total cholesterol, high density lipoprotein (HDL) and low density lipoprotein (LDL). All blood parameters determined with kits from Biosystems, S.A. Costa Brava, 30-Barcelona (Spain).

\section{Statistical analysis:}

The collected data were subjected to analysis of variance using the general linear model (GLM) procedure of SAS User's guide (SAS , 2001). Duncan's Multiple Range test (Duncan's, 1955) was used to separate means when separation was relevant. Statistical significance was accepted at probability level of $(\mathrm{P}<0.05)$ using the following model:

$$
\mathrm{Y}_{\mathrm{ij}}=\mu+\mathrm{T}_{\mathrm{i}}+\mathrm{e}_{\mathrm{ij}} \text {. }
$$

Where: $\mu=$ Overall mean of $Y_{i j}, T_{i}=$ Effect of treatment, $I=(1, \ldots 5) e_{i j}$ $=$ Random error . 
Table 2: Compositions and calculated analysis of the experimental diets.

\begin{tabular}{|c|c|c|c|c|c|}
\hline \multirow[b]{2}{*}{ Ingredients } & \multicolumn{5}{|c|}{ GKM $(\%)$} \\
\hline & $\begin{array}{c}\mathbf{0 . 0} \\
\text { (Control) }\end{array}$ & 2.5 & 5.0 & 7.5 & 10.0 \\
\hline Yellow corn & 19.55 & 18.55 & 19.10 & 21.10 & 22.60 \\
\hline Soy bean meal $44 \%$ & 21.10 & 19.58 & 16.49 & 12.95 & 10.00 \\
\hline Alfalfa hay & $25 . .85$ & 25.85 & 25.85 & 24.35 & 23.35 \\
\hline Wheat bran & 27.50 & 27.50 & 27.50 & 28.00 & 28.00 \\
\hline Guar korma meal (GKM) & 0.00 & 2.50 & 5.00 & 7.50 & 10.00 \\
\hline Di calcium phosphate & 1.50 & 1.50 & 1.50 & 1.50 & 1.50 \\
\hline Limestone & 0.75 & 0.75 & 0.75 & 0.75 & 0.75 \\
\hline Molasses & 3.00 & 3.00 & 3.00 & 3.00 & 3.00 \\
\hline $\mathrm{NaCl}$ & 0.30 & 0.30 & 0.30 & 0.30 & 0.30 \\
\hline Premix* & 0.30 & 0.30 & 0.30 & 0.30 & 0.30 \\
\hline DLMethionine & 0.10 & 0.12 & 0.16 & 0.20 & 0.15 \\
\hline Anticoccidia (Diclazuril) & 0.05 & 0.05 & 0.05 & 0.05 & 0.05 \\
\hline Total & 100 & 100 & 100 & 100 & 100 \\
\hline \multicolumn{6}{|l|}{ Chemical composition (\%) } \\
\hline Crud protein & 18.21 & 18.70 & 18.60 & 18.36 & 18.28 \\
\hline Digestible energy $(\mathrm{kcal} / \mathrm{kg})$ & 2554 & 2552 & 2552 & 2570 & 2584 \\
\hline Crud fiber & 12.77 & 12.85 & 12.85 & 12.46 & 12.19 \\
\hline Ether extract & 2.70 & 2.77 & 2.87 & 3.01 & 3.13 \\
\hline Calcium & 1.10 & 1.10 & 1.09 & 1.07 & 1.05 \\
\hline Total Phosphorus & 0.79 & 0.77 & 0.76 & 0.74 & 0.72 \\
\hline Lysine & 0.99 & 1.00 & 0.98 & 0.94 & 0.91 \\
\hline Methionine & 0.39 & 0.47 & 0.57 & 0.66 & 0.67 \\
\hline Methionine +Cystene & 0.70 & 0.70 & 0.70 & 0.70 & 0.71 \\
\hline $\mathrm{Na}$ & 0.16 & 0.16 & 0.16 & 0.16 & 0.16 \\
\hline Cost / ton at Egyptian Local Price (LE) & 2652 & 2613 & 2561 & 2543 & 2502 \\
\hline
\end{tabular}

*Supplied per $1 \mathrm{~kg}$ diet: $6000 \mathrm{IU}$ vit. A; $900 \mathrm{IU}$, vit. $\mathrm{D}_{3} ; 40 \mathrm{mg}$, vit. E; $2.0 \mathrm{mg}$, vit. $\mathrm{K}_{3} ; 2.0 \mathrm{mg}$ vit., $\mathrm{B}_{1} ; 4.0 \mathrm{mg}$, vit. $\mathrm{B}_{2} ; 2.0 \mathrm{mg}$, vit. $\mathrm{B}_{6} ; 0.010 \mathrm{mg}$, vit. $\mathrm{B}_{12} ; 5.0$ $\mathrm{mg}$, vit. PP; $10.0 \mathrm{mg}$ vit., $\mathrm{B}_{5} ; 0.05 \mathrm{mg}, \mathrm{B}_{8} ; 3.0 \mathrm{mg}, \mathrm{B}_{9} ; 250 \mathrm{mg}$, choline; 50.0 $\mathrm{mg}$, Fe;50.0 mg, Zn; $8.5 \mathrm{mg} \mathrm{Mn} ; 5.0 \mathrm{mg} \mathrm{Cu} ; 0.20 \mathrm{mg} \mathrm{I}$, and $0.01 \mathrm{mg} \mathrm{Se}$.

\section{RESULTS AND DISCUSSION}

\section{1- Doe performance during pregnancy and lactation period}

The effect of GKM on the performance of does during gestation and lactation periods is shown in Table 3. The gestation length and the does' weight after gestation haven't significantly affected by different treatments. Inclusion of GKM in does diet affected significantly both feed intake and change in weight of does during gestation period. The does fed on 0.0 or 5.0 
$\%$ GKM diet recorded the highest feed intake value 4157.30 and $4042.50 \mathrm{~g}$, respectively. The does fed up to 5\% GKM during gestation period recorded the highest change in weight $+132.50 \mathrm{~g}(4.36 \%),+124.38 \mathrm{~g}(3.43 \%)$ and $+100.63 \mathrm{~g}(3.43 \%)$ for 5.0, 0.0 and $2.5 \%$ GKM treatments, respectively. On contrary, increasing GKM more than $5.0 \%$ in does diet decreased feed intake and change in live weight.

In this respect, Kamran el al., (2002) recorded that the broiler chicks significantly gained more weight when fed on $5.0 \%$ guar meal. This gained weight may be due to the reflection of consumed more protein and amino acids and enhanced the digestion. This enhanced may come from the linearly increasing in count of Lactobacillus with decreasing count of cecal Salmonilla spp. and E.Coli by using guar meal. Mohamed (2014) found that, using GKM at levels 2.5, 5.0 and $10.0 \%$ have increased the crypts depth of intestinal jejunum of broiler chicks and the linearly increasing in count of Lactobacillus in contrary with decreasing count of cecal Salmonilla spp. and E.Coli . While, using $5.0 \%$ GKM diet increased body weight gain of chicks. In this respect, GKM had an inhibition action on colonization of pathogenic gastrointestinal bacteria (Bengmark, 1998), and enhanced macrophage activity (Duncan et al., 2002). Because rabbit is a small nonruminant herbivore, rabbit feeding is more similar to ruminant feeding and digestive physiology shows some similarity particularly ceacal processes (Marounek et al., 2000). Fermentation pattern in rabbit cecum resembles that in the rumen; however it shows lower fibrolytic microbial activity and relatively higher amylolytic and proteolytic microbial activity (Gidenne, 1997).

Also, mean values of feed intake during suckling period showed significant increase for does fed diets containing 5.0\% GKM compared with the higher GKM levels. On the other hand, the same does lost more weight $-118.13 \mathrm{~g}(-3.92 \%)$ compared with the other GKM treatment. Inclusion GKM at level $10.0 \%$ more than $5.0 \%$ for does decreased feed intake compared with control group. In this respect, Salma et al., (2015) obtained that, replaced GKM from SBM by $50 \%$ ( $13.5 \%$ from diet for starter and $12.5 \%$ from diet for grower) and $75 \%(20.25 \%$ from diet for starter and $18.75 \%$ from diet for grower) in broiler diet, recorded a decreased in feed intake and Walaa et al., (2014) reported a depression in feed intake when substituted GKM from SBM by $25 \%$ (4\% from diet) and $50 \%$ (8\% from diets) in growing rabbit diets. On contrary with Thakur and Pradhan (1975); Sagar et al., (1978); Gharaei et al., (2012); Mishra el al., (2013) and Nasrala, et al (2015) reported that feed intake was significantly increased with increase GKM percent in poultry diets. Also, Salehpour 
EFFECT OF GUAR KORMA MEAL IN RABBITS DIETS ON PERFORMANCE 7 
et al., (2012) recorded increasing DM intake with decreasing GKM level in cow diets. In dairy cows, palatability problems have been reported when more than $5.0 \%$ guar meal included in the diet. However, dairy cows and heifers fed rations containing $10-15 \%$ guar meal got acquainted to its odor and taste after a few days. Intake remained lower than with the control diet (cottonseed meal) but dairy performances were not affected. In growing dairy calves, flavored guar meal and toasted guar meal gave slightly better rates of intake and gain than raw guar meal (Rahman and Leighton 1968; Singh et al., 2008 and Salehpour et al., 2012).

\section{2- Milk yield during suckling period:}

Table (4) presents results of effect of GKM on milk yield. Does fed on $5.0 \%$ GKM recorded significantly the highest milk yield during four weeks of lactation compared with others groups. However, the does fed on 7.5 and 10.0 $\%$ GKM recorded a depression in milk yield during the four weeks period. Does fed on $2.5 \%$ GKM during four weeks had no negative effect on milk yield compared with control group. The mean value of milk yield during four weeks showed the same trend as weekly recorded values of milk yield.

Table 4: Effect of GKM level on milk yield of does (g/d):

\begin{tabular}{|cccccccc|}
\hline Suckling & \multicolumn{5}{c}{ GKM (\%) } & Pooled & \multirow{2}{*}{ Significance } \\
\cline { 2 - 6 } period & $\mathbf{0 . 0}$ & $\mathbf{2 . 5}$ & $\mathbf{5 . 0}$ & $\mathbf{7 . 5}$ & $\mathbf{1 0 . 0}$ & SE & \\
\hline Week 1 & $78.75^{\mathrm{b}}$ & $80.25^{\mathrm{b}}$ & $101.88^{\mathrm{a}}$ & $71.25^{\mathrm{b}}$ & $68.13^{\mathrm{b}}$ & 4.44 & $* *$ \\
Week2 & $121.25^{\mathrm{b}}$ & $126.88^{\mathrm{b}}$ & $150.00^{\mathrm{a}}$ & $105.00^{\mathrm{c}}$ & $95.63^{\mathrm{c}}$ & 5.34 & $* *$ \\
Week3 & $133.75^{\mathrm{bc}}$ & $144.38^{\mathrm{b}}$ & $190.63^{\mathrm{a}}$ & $117.50^{\mathrm{cd}}$ & $105.00^{\mathrm{d}}$ & 6.54 & $* *$ \\
Week4 & $124.38^{\mathrm{b}}$ & $113.75^{\mathrm{bc}}$ & $153.13^{\mathrm{a}}$ & $100.63^{\mathrm{c}}$ & $73.13^{\mathrm{d}}$ & 5.27 & $* *$ \\
$\begin{array}{c}\text { Overall } \\
\text { mean }\end{array}$ & $114.53^{\mathrm{b}}$ & $116.32^{\mathrm{b}}$ & $148.91^{\mathrm{a}}$ & $98.60^{\mathrm{c}}$ & $85.47^{\mathrm{c}}$ & 4.61 & $* *$ \\
\hline
\end{tabular}

a, b... Means within each row have different letter(s) are significantly different. $* *:(\mathrm{P}<0.01) . \quad \mathrm{GKM}=$ Guar Korma Meal.

In this respect, Salehpour et al, (2012) recorded increasing milk production for cow fed diet containing guar meal $25 \%$ substitution for cotton seed more than control, 50 and $100 \%$ substitution. The increase in milk yield for doe feed on 2.5 and 5\% GKM more than 7.5 and $10 \%$ may be due to the does in those treatment consumed the highest feed intake during suckling period which reflected on milk yield. This result agreed with Salehpour et al., (2012) who reported increasing in DM intake for lactating cows fed on 25 and $50 \%$ GKM substituted for cotton seed. Also, they recorded improving of milk composition for lactated cow feed on guar meal (milk fat, protein and lactose) for all substitution levels. Results of cattle showed that the high content of the guar meal protein offers a good 
source of essential amino acid (Turki etal. 2011). Furthermore the obtained results of milk yield explained the highest body weight loss of 5.0\% GKM does, whereas does produced the biggest milk yield lost more weight.

\section{3-Reproductive performance of does:}

Litter size and mortality rate:

The effects of experimental treatments on litter size and mortality rate during four weeks are shown in Table 5. Litter size at birth and weaning were significantly higher in the control and 5\% GKM groups compared to 2.5 or 7.5 or $10.0 \%$ GKM groups at 28 day of age. The recorded values of litter size at birth showed no significant negative effect of inclusion $2.5 \%$ GKM in dose diets, but after that this level of GKM decreased litter size significantly compared with control and $5 \%$ GKM values. These results recorded the same trend for milk yield of does. Increasing the level of GKM to 7.5 or 10.0 $\%$ had increased the mortality rate numerically. However, the average of mortality rate was not significantly different between different treatments.

Table 5: Effect of GKM level on the litter size and mortality rate of does.

\begin{tabular}{|cccccccc|}
\hline \multirow{2}{*}{ Age } & \multicolumn{9}{c}{ GKM (\%) } & Pooled & \multirow{2}{*}{ Significance } \\
\cline { 2 - 6 } & $\mathbf{0 . 0}$ & $\mathbf{2 . 5}$ & $\mathbf{5 . 0}$ & $\mathbf{7 . 5}$ & $\mathbf{1 0 . 0}$ & SE & \\
Litter size & & & & & & & \\
At birth & $8.00^{\mathrm{a}}$ & $7.13^{\mathrm{ab}}$ & $8.50^{\mathrm{a}}$ & $6.38^{\mathrm{b}}$ & $6.00^{\mathrm{b}}$ & 0.50 & $*$ \\
Week 1 & $7.13^{\mathrm{ab}}$ & $6.25^{\mathrm{bc}}$ & $7.50^{\mathrm{a}}$ & $5.50^{\mathrm{c}}$ & $5.25^{\mathrm{c}}$ & 0.34 & $* *$ \\
Week 2 & $6.75^{\mathrm{a}}$ & $5.88^{\mathrm{b}}$ & $7.13^{\mathrm{a}}$ & $5.00^{\mathrm{c}}$ & $4.63^{\mathrm{c}}$ & 0.26 & $* *$ \\
Week 3 & $6.75^{\mathrm{a}}$ & $5.75^{\mathrm{b}}$ & $6.88^{\mathrm{a}}$ & $4.88^{\mathrm{c}}$ & $4.50^{\mathrm{c}}$ & 0.26 & $* *$ \\
Week 4 & $6.63^{\mathrm{a}}$ & $5.62^{\mathrm{b}}$ & $6.88^{\mathrm{a}}$ & $4.75^{\mathrm{c}}$ & $4.38^{\mathrm{c}}$ & 0.24 & $* *$ \\
$\begin{array}{l}\text { Mortality rate \% } \\
\text { 1-28 days }\end{array}$ & 17.13 & 21.18 & 19.06 & 25.55 & 27.00 & 5.06 & NS \\
\hline
\end{tabular}

a, b... Means within each row have different letter(s) are significantly different.

NS: Not significant, $*:(P<0.05)$, and $* *:(P<0.01)$. GKM= Guar Korma Meal.

\section{Litter weight and litter weight gain:}

Inclusion of GKM in doe diets significantly affected litter weight and their weight gain during four weeks (Table 6). Both values of litter weight and litter weight gain of experimental groups during the overall lactation period (1-4 wks) showed superior values of litters of 5.0 GKM group compared with other treatments followed by control and $2.5 \%$ GKM groups. The total litter weight gain during the four weeks of lactation period increased by $16.0 \%$ for does fed on 5.0 \% GKM diet and decreased by 8.0 $\%, 30.6 \%$ and $40.5 \%$ for the does fed on $2.5 \%, 7.5 \%$ and $10.0 \%$ GKM diets, respectively, compared with control group. 


\section{Performance of kids overall suckling period:}

Results in Table (7) shows mean values of kid weight at birth, kid weight at weaning, kid weight gain and average daily gain. These parameters showed significant differences between treatments. Feeding GKM at $2.5 \%$ and $5.0 \%$ improved kid weight at weaning by 8.4 and 10.6 $\%$ respectively, kids weight gain by 9.1 and $11.8 \%$ and average daily gain 9.2 and $11.8 \%$ respectively compared with control group. This increase is logic with the increasing in milk yield for both treatments. Using more than $5.0 \%$ GKM didn't affect kid weight gain or kid daily gain compared with control group.

The obtained result of mortality rate agreement with Mishra et al., (2013) who reported that mortality was not related to the dietary treatments of GKM to broiler diet (2\% in pre-starter, $5 \%$ in starter and finisher) and there was no significant variation observed between the groups. In this respect, GKM had an inhibition action on colonization of pathogenic gastrointestinal bacteria (Bengmark, 1998). However, the highest insignificant rate of mortality for the does fed on 7.5 and $10.0 \%$ GKM are in agreement with Rahman and Leighton (1968) who found that excessive concentrations of guar meal in poultry diets caused diarrhea and increased mortality of broilers.

Table 7: Effect of GKM on the productive traits of kids over all suckling period.

\begin{tabular}{|lccccccc|}
\hline Items (g) & \multicolumn{5}{c}{ GKM\% } & Pooled & \multirow{2}{*}{ Sign. } \\
\cline { 2 - 5 } & $\mathbf{0 . 0}$ & $\mathbf{2 . 5}$ & $\mathbf{5 . 0}$ & $\mathbf{7 . 5}$ & $\mathbf{1 0 . 0}$ & SE & \\
\hline Kid weight at birth & 47.34 & 48.74 & 47.94 & 45.65 & 43.54 & 1.64 & NS \\
kid weight at weaning & $408.19^{\mathrm{b}}$ & $442.62^{\mathrm{a}}$ & $451.50^{\mathrm{a}}$ & $401.33^{\mathrm{bc}}$ & $375.57^{\mathrm{c}}$ & 10.48 & $* *$ \\
Kid weight gain $^{3}$ & $360.85^{\mathrm{b}}$ & $393.88^{\mathrm{a}}$ & $403.56^{\mathrm{a}}$ & $355.68^{\mathrm{b}}$ & $332.03^{\mathrm{b}}$ & 10.18 & $* *$ \\
Kid daily gain & $12.89^{\mathrm{b}}$ & $14.08^{\mathrm{a}}$ & $14.41^{\mathrm{a}}$ & $12.70^{\mathrm{b}}$ & $11.86^{\mathrm{b}}$ & 0.36 & $* *$ \\
\hline
\end{tabular}

, b... Means within each row have different letter(s) are significantly different. NS: Not significant $* *:(P<0.01)$. GKM= Guar Korma Meal.

The enhancing of litter and kid weight gain of GKM treatment up to $5.0 \%$ agree with Kamran el al., (2002) who recorded that the broiler chicks significantly gained more weight when fed on $5.0 \%$ GKM. Turki et al. (2011) indicated an improvement in sheep body weight with 15\% GKM feeding. On contrary Rajput et al., (1998) reported that increasing GKM level in diets decreased BWG and agree with Edward et al., (1988) who reported that GKM depressed the digestibility of starch and deprive the birds of the available energy. Increasing level of GKM than $5.0 \%$ had a depression effect in litter gain which may be due to increase the anti- 
nutritional agents as guar gum, tripsin inhibitor, saponins, poliphenols and hemagelotenins (Verma and Mc-Nab, 1982; Conner, 2002; and Lee et al., 2003). Also, high content of galactomannan gum in guar meal can increase intestinal viscosity, suppress growth (Burnett, 1966; Lee et al., 2003 and Gutierrez et al., 2007).

The presented results of litter size, mortality rate and litter weight in kids Tables (5, 6 and 7) are in good harmony with the results of milk yield, whereas inclusion $5.0 \%$ of GKM in does diets increased milk yield significantly compared with other groups. That excess of milk yield saved more quantities of nutrients for kids to survive and growth compared with rates in other treatments. In addition the increased average daily of kid of $2.5 \%$ and $5.0 \%$ GKM treatments during suckling period might be improving the general microbial status of their colon due to beginning of feeding from their mothers feed (Bengmark, 1998; Duncan et al., 2002 and Mohamed, 2014).

\section{4-Blood biochemical analysis:- a-Plasma proteins and liver function:}

As shown in Table 8, adding 5.0\% GKM to doe rabbit diets significantly increased concentrations of total protein and globulin compared to other groups, while decreased albumen/globulin ratio compared with $10.0 \%$ GKM group. These results indicated that inclusion 5.0\% GKM in does diet might be improved rabbit immunity and protein supply to milk production compared with other treatments. Adding the GKM to doe rabbits diet did not alter activities of AST and ALT enzymes compared to untreated control group and that mean, these treatment GKM haven't adverse effect on liver function. The obtained results showed increased level of total protein albumen by inclusion $2.5 \%$ and $5.0 \%$ of GKM in does diet, however the experimental diets of all treatments were formulated to be equal in protein and digestible energy. These results might be support the suggestion of improving performance through enhancing the microbial status of colon by using GKM as feed ingredient (Bengmark, 1998; Duncan et al., 2002 and Mohamed, 2014). The high content of the guar meal protein offers a good source of essential amino acids for cattle (Turki et al., 2011) and enhancing the digestion. On contrary, Salma et al., (2015) found that the concentrations of total protein, albumin and globulin in blood serum of broiler decreased significantly with replaced GKM at $25 \%$ and $50 \%$ and $75 \%$ from SBM diets compared with control group. 
Table 8: Biochemical parameters in blood of doe rabbits of the experimental groups.

\begin{tabular}{|c|c|c|c|c|c|c|c|}
\hline \multirow{2}{*}{ Items } & \multicolumn{5}{|c|}{ GKM (\%) } & \multirow{2}{*}{$\begin{array}{l}\text { Pooled } \\
\text { SE }\end{array}$} & \multirow{2}{*}{ Sign. } \\
\hline & $\mathbf{0 . 0}$ & 2.5 & 5.0 & 7.5 & 10.0 & & \\
\hline \multicolumn{8}{|c|}{ Plasma protein and liver function } \\
\hline Total protein $(\mathrm{g} / \mathrm{dl})$ & $5.39^{\mathrm{b}}$ & $5.51^{\mathrm{b}}$ & $6.13^{\mathrm{a}}$ & $5.20^{\mathrm{bc}}$ & $4.85^{\mathrm{c}}$ & \pm 0.13 & $*$ \\
\hline Albumin $(\mathrm{g} / \mathrm{dl})$ & $2.75^{\mathrm{b}}$ & $2.82^{\mathrm{ab}}$ & $2.98^{\mathrm{a}}$ & $2.77^{\mathrm{b}}$ & $2.70^{\mathrm{b}}$ & \pm 0.06 & * \\
\hline Globulin (g/dl) & $2.64^{\mathrm{b}}$ & $2.69^{b}$ & $3.15^{\mathrm{a}}$ & $2.43^{\mathrm{bc}}$ & $2.15^{\mathrm{c}}$ & \pm 0.15 & $*$ \\
\hline Albumin/ Globulin ratio & $1.04^{\mathrm{ab}}$ & $1.05^{\mathrm{ab}}$ & $0.95^{\mathrm{b}}$ & $1.14^{\mathrm{ab}}$ & $1.26^{\mathrm{a}}$ & \pm 0.08 & $*$ \\
\hline Activity of AST (U/ml) & 32.03 & 31.41 & 31.34 & 31.77 & 31.87 & \pm 0.73 & NS \\
\hline Activity of ALT (U/ml) & 24.07 & 24.69 & 25.86 & 23.94 & 25.35 & \pm 0.68 & NS \\
\hline \multicolumn{8}{|l|}{ Plasma lipids and glucose } \\
\hline Triglycerides (mg/dl) & $146.5^{\mathrm{a}}$ & $136.93^{\mathrm{b}}$ & $123.65^{c}$ & $132.03^{\mathrm{b}}$ & $135.71^{b}$ & \pm 12.75 & $*$ \\
\hline $\begin{array}{l}\text { Total cholesterol } \\
(\mathrm{mg} / \mathrm{dl})\end{array}$ & $88.54^{\mathrm{a}}$ & $81.85^{b}$ & $76.20^{\mathrm{b}}$ & $80.87^{\mathrm{b}}$ & $79.83^{b}$ & \pm 9.93 & $*$ \\
\hline $\mathrm{HDL}(\mathrm{mg} / \mathrm{dl})$ & $45.65^{\mathrm{a}}$ & $39.08^{b}$ & $35.11^{\mathrm{b}}$ & $36.87^{\mathrm{b}}$ & $38.97^{\mathrm{b}}$ & \pm 5.63 & $*$ \\
\hline LDL (mg/dl) & $37.82^{\mathrm{a}}$ & $30.87^{\mathrm{b}}$ & $27.65^{\mathrm{b}}$ & $27.98^{b}$ & $33.17^{\mathrm{b}}$ & \pm 5.07 & $*$ \\
\hline Glucose (mg/dl) & $123.90^{\mathrm{ab}}$ & $122.31^{\mathrm{b}}$ & $131.13^{\mathrm{a}}$ & $112.8^{\mathrm{c}}$ & $121.4^{\mathrm{b}}$ & \pm 2.46 & $*$ \\
\hline
\end{tabular}

a, b.... Means within each row have different letter(s) are significantly different.

NS: Not significant, $*:(P<0.05), \quad$ GKM= Guar Korma Meal.

\section{b-Plasma lipids and glucose:}

According to results in Table (8), adding GKM at levels 2.5, 5.0, 7.5 or $10.0 \%$ to doe rabbits diet enhance plasma lipid profile whereas concentrations of total cholesterol, HDL, LDL and triglycerides, while concentration of glucose was increased significantly by using 5.0 \% GKM compared with 2.5, 7.5 and $10.0 \%$ inclusion rate of GKM in does rabbit diet. Numerous investigations have shown some useful physiological functions of galactomannans, such as those found in guar meal. These functions include decrease in plasma cholesterol (Maisonnier et al., 2001), plasma glucose (Ou et al., 2001). The obtained results of $5.0 \%$ (GKM) may be due to lower lipid metabolism by lowers cholesterol and LDL in body pool. In this respect Salma et al., (2015) recorded that serum triglycerides, cholesterol, HDL and LDL concentrations decreased significantly for group fed on control group followed by the group fed on (GKM-25\% substitution for SBM), while (GKM-75\% substitution for SBM) had the highest concentrations. Cholesterol was significantly affected by experimental treatments; these probably were because of the eating of high levels of guar meal .In other studies authors reported that the high viscosity of guar gum may contribute to some beneficial physiological functions including decreasing plasma cholesterol (Fairchild et al., 1996; and Ou et al., 2001). On contrary with, (Shahbazi, 2012) who found that blood biochemical parameters were not affected by guar meal including 
three levels of GKM $\left(0.0,25\right.$ and $\left.50.0 \mathrm{~g} \mathrm{~kg}^{-1}\right)$ except for the serum level of cholesterol was increased.

On the other hand Mohamed and Kazem (2012) showed that intermediate and high GKM levels in diets (4 and $6 \%$ ) increased plasma triglycerides compared to the control group. Also there was a tendency for LDL to be affected by experimental groups. Plasma HDL was higher than the control group in the birds fed on the diet contained high levels of GKM $(6 \%)$. Triglycerides, cholesterol and HDL were significantly affected by experimental treatments.

According to the overall results of growth performance and physiological measurements, using GKM at level $5.0 \%$ compared with other treatments showed the best performance. This may be due to increasing the Lactobacillus with decreasing count of cecal Salmonilla spp. and E.Coli (Mohamed 2014), or increasing blood protein or decreased triglyceride and LDL and that due to enhance blood circulation and metabolism and the useful of nutrients.

\section{Feed cost:}

Results of feeding cost for does fed GKM are summarized in Table 9. Using GKM decreased price of $\mathrm{kg}$ feed and total feed cost does compared with control group. However, the relative difference of feeding cost of each treatment to control showed that, the group feed on $5.0 \%$ GKM (which recorded the best performance and the highest litter size) saved cost more than other groups when was taken the litter size in consideration. That's served our aimed to find cheaper protein source.

Table 9. Effect of guar korma meal on feeding cost of rabbit does.

\begin{tabular}{|lccccc|}
\hline \multirow{2}{*}{ Items } & \multicolumn{5}{c|}{ GKM (\%) } \\
\cline { 2 - 6 } & $\mathbf{0 . 0}$ & $\mathbf{2 . 5}$ & $\mathbf{5 . 0}$ & $\mathbf{7 . 5}$ & $\mathbf{1 0 . 0}$ \\
\hline Price/kg diet $(\boldsymbol{L E})$ & 2.65 & 2.61 & 2.56 & 2.51 & 2.5 \\
Total feed intake/ doe/gestation & 10.05 & 9.61 & 10.36 & 9.34 & 9.35 \\
and suckling period(kg) & 6.63 & 5.62 & 6.88 & 4.75 & 4.38 \\
Litter size at weaning & 26.60 & 25.08 & 26.52 & 23.44 & 23.38 \\
Total feed cost/doe (LE) & 4.01 & 4.46 & 3.85 & 4.93 & 5.34 \\
$\begin{array}{l}\text { Total feed cost/ litter (Total } \\
\text { feed coast/litter size at weaning) }\end{array}$ & & 11.22 & 3.40 & 22.94 & 33.17 \\
Relative difference of feeding & -- & (increase & (saving & (increase & (increase \\
cost from control*(\%) & & cost) & cost) & cost) & cost) \\
\hline
\end{tabular}

- Relative difference of feeding cost from control $=100 \times($ Feeding cost/doe each treatment - Feeding cost/doe of control group)/ Feeding cost/doe of control group). 
Conclusively, from these results it could be recommended to include guar korma meal (GKM) in doe-rabbit diet up to $5.0 \%$ of the diet without negative effect on performance during gestation and lactation periods. In addition, using 5.0 \% GKM saved some of feeding cost/ weaning litter more than other group compared with control group.

\section{REFERENCES}

Anderson, J. O. and Warnick, R. E. (1964). Value of enzyme supplements in rations containing certain legume seed meals or gums. Poultry Science, (43):1091-1097.

Bengmark, S. (1998). Immunonutrition: Role of biosurfactants, fiber, and probiotic bacteria. Nutr., (14): 585-594.

Burnett, G.S. (1966). Studies of viscosity as the probable factor involved in the improvement of certain barleys for chickens by enzyme supplementation. Br. Poultry Sci., 7: 55-75.

Conner, S. (2002). Characterization of guar meal for use in poultry rations. Ph.D. Dissertation. Texas A\&M University, College Station, TX.

Duncan, C.J., Pugh, N., Pasco, D.S. and Ross, S.A. (2002). Isolation of a galactomannan that enhances macrophage activation from the edible fungus Morchella esculenta. J. Agric. Food Chem., 50: 5683-5685.

Duncan, D.B., (1955). Multiple range and multiple F tests. Biometrics, 11: $1-42$.

Edward, C. A., Johnson, I. T. and Read, N. W. (1988). Do viscous polysaccharides siow absorption by inhibitin diffusion or convection. European J. of Clinical Nutr., 42:306-312.

Fairchild, R.M., Ellis, P.R., Byrne, A.J., Luzio, S.D. and Mir, M.A. (1996). A new breakfast cereal containing guar gum reduces postprandial plasma glucose and insulin concentrations in normalweight human subjects. Br. J. Nutr., 76: 63-73.

Gharaei, M. A., Dastar, B., Nameghi, A. H., Taber, G. H. and Shargh, M. S. (2012). Effects of guar meal with and without $\beta$-mannanase enzymes on performance and immune response of broiler chicks. Int. Res. J. Appl. Basic Sci., 3(s): 2785-2793.

Gidenne, T. (1997). Caeco-colic digestion in the growing rabbit :impact of nutritional factors and related disturbances. Livestock Production Sci., 51:73-88.

Gutierrez, O. C., Zhang, A.L., Cartwright, J.B. and Careyand, C.A. B. ( 2007). Use of guar by product in high production laying hen diets. Poultry Sci., 86: 1115-1120. 
Hassan, S. M., Haq, A. U., Byrd, J. A., Berhow, M. A., Cartwright, A. L. and Bailey, C. A. (2010). Haemolytic and antimicrobial activities of saponin-rich extracts from guar meal. Food Chem., 119: 600-605.

Heo, P. S., Lee, S. W., Kim, D. H., Lee, G. Y., Kim, K. H. and Kim, Y. Y. (2009). Various levels of guar meal supplementation on growth performance and meat quality in growing-finishing pigs. J. Anim. Sci., 87, E-Suppl. 2: 144

Kamran, M., Pasha, T. N., Mahmud, A. and Ali, Z. (2002) Effect of commercial enzyme (Natugrain) supplementation on the nutritive value and inclusion rate of guar meal in broiler rations. International Journal of Poultry Science, 1(6): 167-173.

Lee, J. T., Bailey, C. A. and Cartwright, A. L. (2003). Guar meal germ and hull fractions differently affect growth performance and intestinal viscosity of broiler chickens. Poultry Science, 82: 1589-1595.

Lee, J. T., Conner-Appleton, S., Haq, A. U., Cartwright, A. and Bailey, C. (2004) Quantitative measurement of negligible trypsin inhibitor activity and nutrient analysis of guar meal fractions. Journal of Agricultural and Food Chemistry, 52: 6492-6495.

Lee, J. T., Connor, S., Cartwright, A. and Bailey, C. (2005). Effects of Guar Meal By-Product with and without $\beta$ - mannanase Hemicell on Broiler Performance. Poultry Science, 84: 1261-1267.

Lee, J. T.; Bailey, C. A. and Cartwright, A. L. (2009). In vitro viscosity as a function of guar meal and beta-mannanase content of feeds. Int. J. Poult. Sci., 8(8): 715-719

Maisonnier, S., Gomez J. and Carre B. (2001). Nutrient digestibility and intestinal viscosities in broiler chickens fed on wheat diets, as compared to maize diets with added guar gum. Br. Poultry Sci., 42:102-110.

Marounek, M., Brezina, P. and Baran, M. (2000). Fermentation of carbohydrates and yield of microbial protein in mixed cultures of rabbit caecal microorganisms. Archives of Animal Nutrition, 53:241252.

Mishra, A.; Sarkar, S. K.; Ray S. and Haldar, S. (2013). Effects of partial replacement of soybean meal with roasted guar korma and supplementation of mannanase on performance and carcass traits of commercial broiler chickens. Available at www. Veterinary world. org/Vol.6/Sept-2013/21.pdf

Mohamed, M. and Kazem, K. (2012). The effect of guar meal (germ fraction) and $\beta$ - mannanase enzyme on growth performance and plasma lipids in broiler chickens. African J. of Biotechnology, 11 (35):8767-8773. 
Mohamed, M.E. (2014). Effect of guar meal inclusion in diet on performance, bacterial population and intestinal of broiler chicks. Egyptian J. Nutrition and feeds, 17 (2): 329-337.

Nasrala, M.M., Waly A. H., Habib, H.H., Abdel Magied, H.A.; Assaf, I.M.M. and Ouda, M.M. (2015). Effect of dietary inclusion of guar korma meal levels with or without enzyme supplementation on performance of local strain chicks (Anshas). Egyptian J. Nutrition and Feeds, 18(2) Special Issue: 323-3.

NRC (1977). National Research Council. Nutrient Requirements Of Rabbits. Nat. Acad. Sci., Washington, DC., USA.

Ou, S., Kwok, K., Li , Y. and Fu, L. (2001). In vitro study of possible role of dietary fiber in lowering postprandial serum glucose. J. Agric. Food Chem., 49: 1026-1029.

Rahman, M. and Shafivr M. (1967). Guar meal in dairy cattle rations. Dissertation in partial fulfillment of the requirements for the degree of Doctor of philosophy, Texas A\&M University, College Station, Texas, United States of America.

Rahman, M. S., Leighton, R. E. (1968). Guar meal in dairy rations. $J$. Dairy Sci.,(10):1667-1671

Rajput, L. P., Ramamani, S., Haleem, M. A. and Sub-ramanian, N. (1998). Chemical and biological studies on processed guar meal. Ind. J. Poultry Sci., 331:15-25.

Sagar, V., Prasad, D., Thakur, R. S. and Pradhan, K. (1978). Nutritional evaluation of processed guar (Cyamopsis tetragonoloba) meal for broilers. Ind. J. Poultry Sci., 13:155-160.

Salehpour, M., Qazvinian,K., Vasco A. and Cadavez, P. (2012). Effect sof feeding different levels of guar meal on performance and blood metabolites in holstein lactating cows. Animal Science journal, vol. 55 pages: 73 - 77. Scientific papers : Series D, Animal Science., 22855750 (Print).Issues in Volume LV.

Salma, H. Abu Hafsa, M. M. Basyony and A. A. Hasan (2015). Effects of partial replacement of soybean meal with different levels of guar korma meal on growth performance, carcass traits and blood metabolism of broiler chickens. Asian J. of Poultry Sci., 9(3) ISSN 1819-3609 / DOI: 10.3923/ajpsaj.2015.

SAS, Statistical Analysis System, (2001). User's Guide Version 8.2, Cary NC. USA.

Shahbazi, H.R. (2012). Dietary inclusion of guar meal supplemented by Bmannanase II) evaluation egg quality characteristics and blood parameters of laying hens. Global Vet., 9: 67-72. 
Singh, N., Arya, R. S., Sharma, T., Dhuria, R. K. and Garg, D. D. (2008). Effect of feeding of cluster bean (Cyamopsis tetragonoloba) straw based complete feed in loose and compressed form on rumen and haemato-biochemical parameters in Marwari sheep. Vet. Prac.

Srivastava, S., Anees, K. and Ramani, R. (2011). Promise of guar meal Science reporter. Internet Research, 38-39.

Thakur, R. S. and Pradhan, K. (1975). A note on inclusion of guar meal (Gyamopsis tetragonoloba) in broiler rations. Ind. J. Anim. Sci. ,45:98102.

Turki, I.Y., Elkadier, O.A, ELAmin, M., Zuber, D. E.l. and Hassabo, A. A. (2011). Effect of guar meals and oilseed cakes on carcass characteristics and meat quality attributes of beef cattle. ACTBiotechnology Research Communications, 1:(2) 66-75

Verma, S. V. S. and Mc-Nab, J. M. (1982). Guar meal in diets for broiler chickens. Br. Poultry Sci., 23: 95-105.

Walaa, A. Salama, Hassanein, H.A.M.; Fayed, A.M.A. and Awadinm N.B. (2014). Effect of feeding guar korma meal with or without $\beta$-mannase suplementtion on performance of new-zealand white growing rabbits. The $7^{\text {th }}$ International Conference on Rabbit Production in Hot Climate, 8-12 September, 321-334. 
تأثير كسب الجوار كورما فى علائق أمهات الأرانب النيوزيلاندى الأبيض

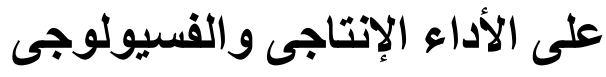

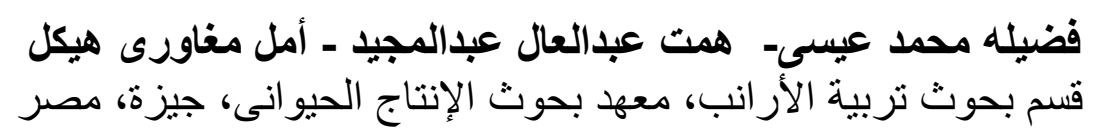

تمت هذه الدر اسه لتقيم تأثثر إدخال معدلات من كسب الجوار (Gyamopsis)

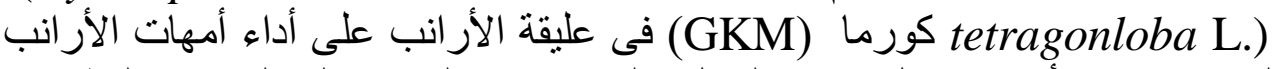

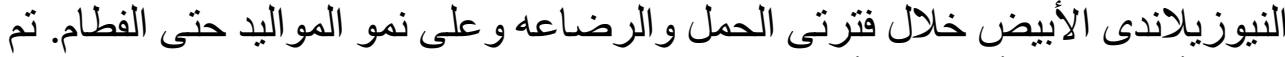

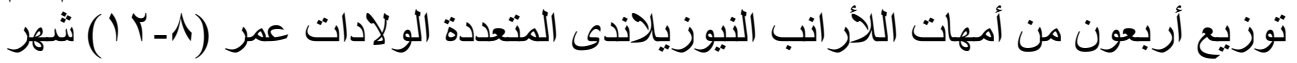

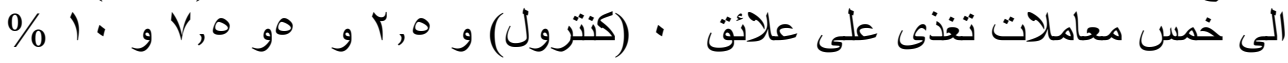

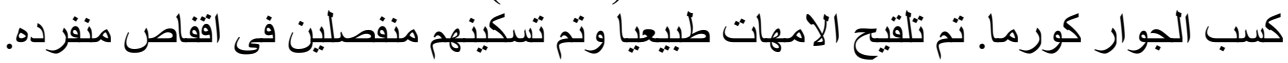

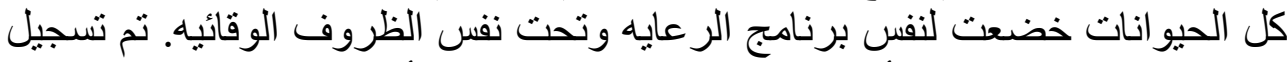

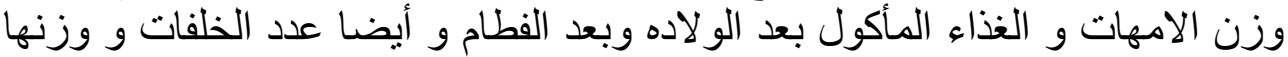

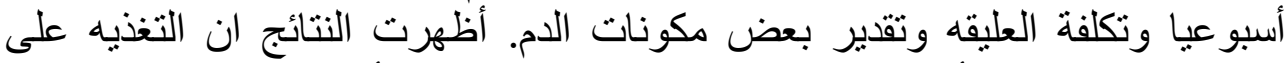

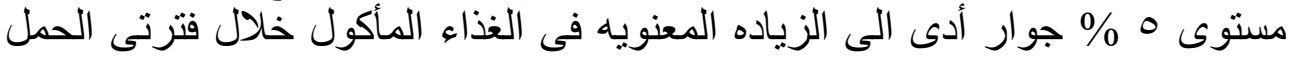

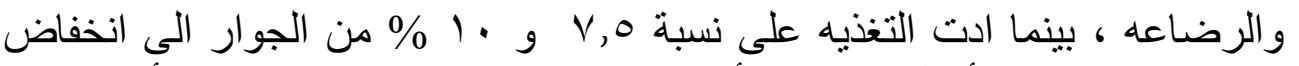

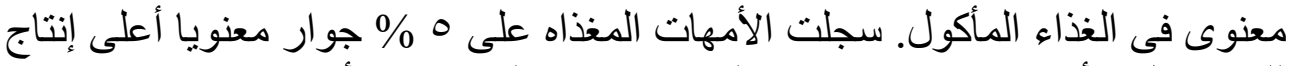

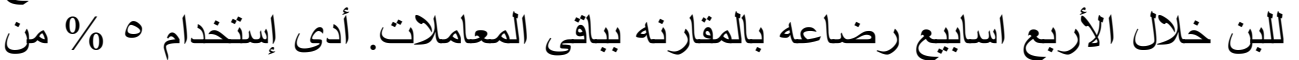

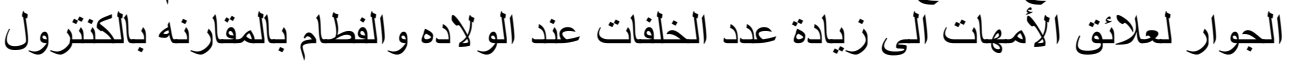

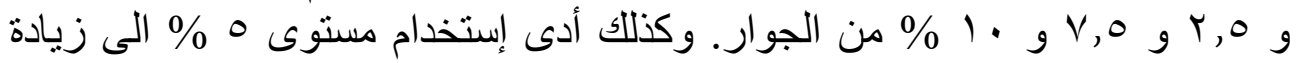

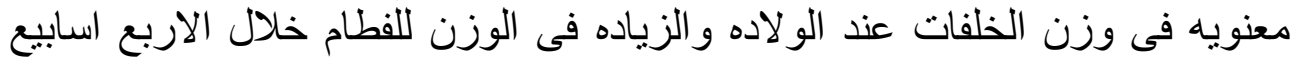

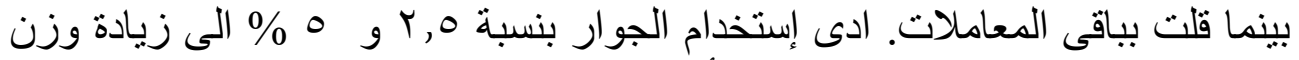

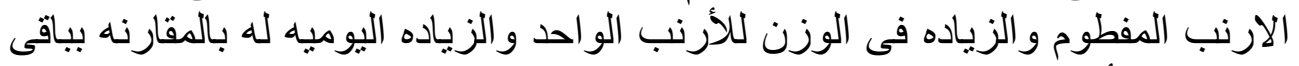

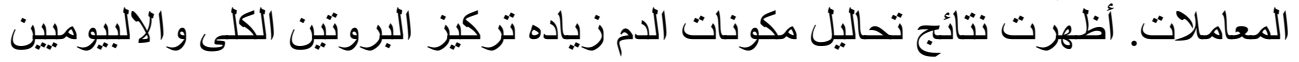

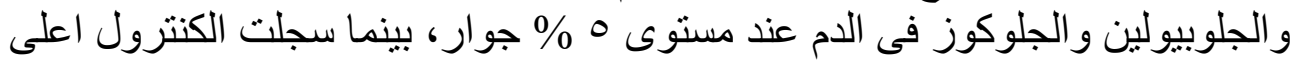
تركيز للجلسريدات الثثلاثيه و الكوليسترول الكلى و الليبوبروتينات المنخفضة الكانيات الكثافه

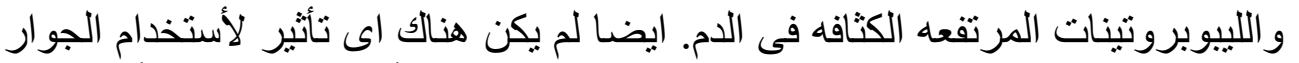
فى العليقه على نشاط انزيمات الكبد ALT, AST ـ كما أوضحت النته النتائج أن العليقه

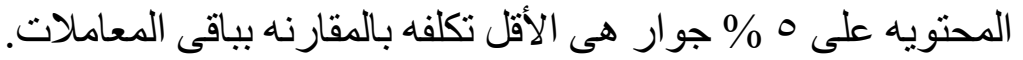

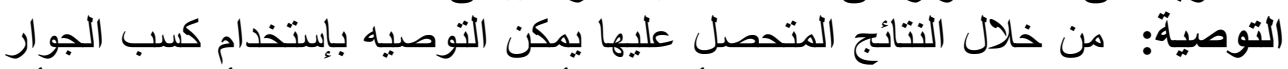

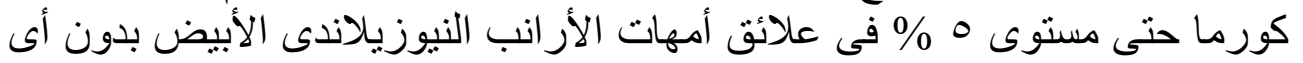

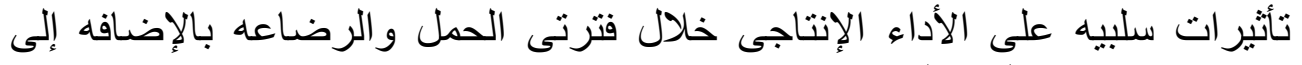
توفير جزء من تكاليف التغذيه عند مستوى 0 \% 